$=2: 3$ とする）を高温 $\mathrm{X}$ 線回折計で $750 \sim 850^{\circ} \mathrm{C}$ の各温度に長 時間保持して回折図形の変化をしらべた限りでは，その生成が認 められなかった。これは Bartram らとは使用した $\mathrm{TiO}_{2}$ 原料が 異なることによるのではないかと思われる(2.4 参照)。

$$
\begin{aligned}
2 \mathrm{ZnO}+3 \mathrm{TiO}_{2} & =\mathrm{Zn}_{2} \mathrm{Ti}_{3} \mathrm{O}_{8} \\
2 \mathrm{ZnTiO}_{3}+\mathrm{TiO}_{2} & =\mathrm{Zn}_{2} \mathrm{Ti}_{3} \mathrm{O}_{8} \\
\mathrm{Zn}_{2} \mathrm{TiO}_{4}+2 \mathrm{TiO}_{2} & =\mathrm{Zn}_{2} \mathrm{Ti}_{8} \mathrm{O}_{8}
\end{aligned}
$$

また Bartram らは $\mathrm{Zn}_{2} \mathrm{Ti}_{3} \mathrm{O}_{8}$ が $900^{\circ} \mathrm{C}$ 以上では（5）式の 逆方向に熱分解すると述へている。

このよ5に $\mathrm{ZnTiO}_{\mathbf{3}}$ の分解はかなり複雑な現象であるが，ここ では純粋の $\mathrm{ZnTiO}_{3}$ を用い, 高温 $\mathrm{X}$ 線回折計で次の各温度に保 持して (970, $\left.1000,1025^{\circ} \mathrm{C} \pm 5^{\circ} \mathrm{C}\right), \mathrm{ZnTiO}_{3}$ の特徽回折線 (104) の強度の経時変化を自動記録して分解速度を求めた結果, この分 解反応が形式的には 2 次式 $\left(\mathrm{d} x / \mathrm{d} t=k(a-x)^{2}\right)$ に従らことが認め られた。なお等モルの $\mathrm{ZnO}$ を混合した際の反応にはこの実験式 は適用できない。

\section{4 反応の機模に成する考察}

以上報告した実験事実をまとめると次の通りである。i） $\mathrm{Zn}_{2}$. $\mathrm{TiO}_{4}$ は原料混合物を $1000^{\circ} \mathrm{C}$ 以上の高温度に加熱すれば容易に えられる。ii） ZnO の蒸気压は高温では，かなり大きい。 iii） $\mathrm{TiO}_{2}$ と $\mathrm{ZnO}$ との粉末混合物を加熱すると， $\mathrm{Zn}_{2} \mathrm{TiO}_{4}$ ととるに $\mathrm{ZnTiO}_{3}$ が常に接近した温度領域で生成する。iv）原料の履歴, 混合比のいかんにかかわらず，加熱過程で常に $\mathrm{ZnTiO}_{3}$ が生成 する。 v） $\mathrm{ZnTiO}_{\mathrm{s}}$ は $970^{\circ} \mathrm{C}$ 以上の高温では，分解する。 vi） $\mathrm{ZnTiO}_{3}$ と $\mathrm{ZnO}$ との混合物の反応温度はかなり低く, $\mathrm{TiO}_{2}$ と $\mathrm{ZnO}$ との混合物を加熱した際の $\mathrm{Zn}_{2} \mathrm{TiO}_{4}$ の生成温度に，ほぼ一 致する。vii）摩破によって活性化された $\mathrm{TiO}_{2}$ を用いると，
$\mathrm{ZnTiO}_{3}$ の生成は著しく促進されるが, $\mathrm{Zn}_{2} \mathrm{TiO}_{4}$ の生成には影響 しない。 viii） $\mathrm{ZnO}$ の履歴は反応に $\mathrm{TiO}_{2}$ ほどには影響を与え ない。ix）粉末の混合度および成型圧力は反応に大きな影響を 与えない。 $\mathrm{x}$ ) 原料の混合比をかえて加熱した際に, $\mathrm{TiO}_{2}$ 過鄱 の領域では $\mathrm{ZnO}$ の回折線の消隇がはやく, $\mathrm{ZnO}$ 過鄱の領域では 反応の完結がおそい。 $\mathrm{xi}$ ) 沸点以下の融解 $\mathrm{ZnCl}_{2}$ 中で $\mathrm{TiO}_{2}$ を 加熱すると $\mathrm{ZnTiO}_{3}$ たけが生成する。

ここで ii)，viii)，ix）抽よ゙ vii）の諸事実を総合すれば，反 応は粉末粒子相互の接触点を通しての拡散だけでなく、 $\mathrm{TiO}_{2}$ 粒 子の表面への $\mathrm{ZnO}$ の気相表面払散が重要な役割を演じているも のと思われ, $\mathrm{TiO}_{2}$ 粉末粒子の表面は, 反応の初期段階において すでに $\mathrm{ZnO}$ で覆われ，反応の律速過程は $\mathrm{TiO}_{2}$ 粒子に対する $\mathrm{Zn}^{2+}$ イオンの拡散にあると仮定すれば $\mathrm{x}$ ）の事実も無理なく理 解することができる※7。

また iii)，iv)，v)，vi)，vii)，xi）の諸事実から，この系で は（6）式および（7）式で示される反応が，並行して進行する （並発反応）とするょりも，ます（6）式の反応で中間化合物と

$$
\begin{aligned}
\mathrm{ZnO}+\mathrm{TiO}_{2} & =\mathrm{ZnTiO}_{3} \\
2 \mathrm{ZnO}+\mathrm{TiO}_{2} & =\mathrm{Zn}_{2} \mathrm{TiO}_{4}
\end{aligned}
$$

して $\mathrm{ZnTiO}_{3}$ が生成し, 第 2 段階で（2）式の過程によって, $\mathrm{Zn}_{2} \mathrm{TiO}_{4}$ を形成する（逐次反応）と考えるのが妥当であると思わ れる。

(1962 年 4 月, 日本化学会第 15 年会一部講演)

この研究には昭和 35 および 36 年度の河上記念財団研究助成 金の補助を得たことを深く感謝致します。

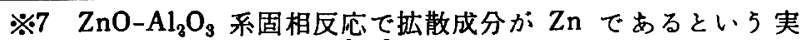
験結果 : R. Linder, Å. Åkerström, Z. Phys. Chem. N. F. 6, 162 (1956) などとも矛盾しない。

\title{
石灰一酸化 ク口ム系化合物†
}

(昭 和 37 年 8 月 6 日受理)

\author{
西 野 忠*・茂木 今朝吉**
}

\begin{abstract}
炭酸カルシウム $\left(\mathrm{CaCO}_{3}\right)$ と酸化クロム $\left(\mathrm{Cr}_{2} \mathrm{O}_{3}\right)$ の混合物を空気中で加熱したときに生成する新化合物の組成拉よび, $\mathrm{Ca}_{3}\left(\mathrm{CrO}_{4}\right)_{2}$ の生成機構などにつたて示差熱分析，熱天科，X線分析怙よび化学分析を行なって検討した。高石灰側の加 熱試料の $d=2.90,2.86,2.81 \AA$ に特徽 3 重線をもつ新化合物は, 遊離石灰の出現, 熱分析などの結果から検討して, $\mathrm{Ca}_{7} \mathrm{Cr}_{4} \mathrm{O}_{17}$ に相当すると考えられる。 $\mathrm{Ca}_{7} \mathrm{Cr}_{4} \mathrm{O}_{17}$ は $\mathrm{CaO} / \mathrm{Cr}_{2} \mathrm{O}_{3}$ (モル比) が 3.5 以上では単一化合物として安定である。 モル比が 2 3.5 では, クロム酸カルシウム $\left(\mathrm{CaCrO}_{4}\right)$ およ゙ $\mathrm{Ca}_{7} \mathrm{Cr}_{4} \mathrm{O}_{17}$ が共存し, $950^{\circ} \mathrm{C}$ 付近で, 両者は反応して, $\mathrm{Ca}_{8}\left(\mathrm{CrO}_{4}\right)_{2}$ を与える。 $\mathrm{Ca}_{3}\left(\mathrm{CrO}_{4}\right)_{2}$ は $950^{\circ} \mathrm{C}$ 以上に拀いてのみ安定で, 徐冷すると $820^{\circ} \mathrm{C}$ 付近で $\mathrm{CaCrO}_{4}$ と $\mathrm{Ca}_{7} \mathrm{Cr}_{4} \mathrm{O}_{17}$ の混合物となる。
\end{abstract}

\section{1 楮专}

著者らは酸化マグネシウムの焼結におよぼす添加剤に関する研 究の一つとして， $\mathrm{CaO}-\mathrm{R}_{2} \mathrm{O}_{3}$ ( $\mathrm{R}$ は 3 価の金属) をとりあげ， $\mathrm{R}$

†本報を「石灰一酸化クロムを主系とする反応の研究（第 1 報)」とする.

* 武藏工業大学化学教室 : 東京都世田ヶ谷区玉川等々力町.

$* *$ 千葉大学工学部：松戸市岩瀬.
$=\mathrm{Cr}$ の場合についてはすでK報告し1)， $\mathrm{R}=\mathrm{Fe}$ の場合2) と反応 様式が著しく異なることを述べた。すなわち， $\mathrm{CaO}-\mathrm{Cr}_{2} \mathrm{O}_{3}$ 系混 合物を空気中で加熱すると，初期に，比較的低温度で $\mathrm{CaCrO}_{4}$ を生成する。しかし $\mathrm{CaO} / \mathrm{Cr}_{2} \mathrm{O}_{3}$ (モル比) が異なれば、 $\mathrm{CaCrO}_{4}$ に対する $\mathrm{CaO}, \mathrm{Cr}_{2} \mathrm{O}_{3}$ などの反応により高温度 $\left(800^{\circ} \mathrm{C}\right.$ 以上) で

1）西野，茂木，案協 69，70 (1961).

2）西野，茂木，密協 69，43 (1961)。 
は数種の化合物が得られることは Ford $ら^{3)}$ が報告した相図から も推察される。Glasser ら") 化合物として $\mathrm{Ca}_{3}\left(\mathrm{CrO}_{4}\right)_{2}$ を挙げている。これは Ford らが推定 した化合物 $9 \mathrm{CaO} .4 \mathrm{CrO}_{3} \cdot \mathrm{Cr}_{2} \mathrm{O}_{3}$ に代るものである。 $\mathrm{Ca}_{3}\left(\mathrm{CrO}_{4}\right)_{2}$ の存在を確認した根拠として, $\mathrm{Ca}_{3}\left(\mathrm{PO}_{4}\right)_{2}$ のX線回折像の近似性 (同形), $2 \mathrm{CaO} \cdot \mathrm{SiO}_{2} の \alpha^{\prime} \rightleftarrows \gamma$ 転移 (Dusting) 防止効果として の類似性であった。鈴木ら それとほぼ等しいことから $\mathrm{Ca}_{3}\left(\mathrm{CrO}_{4}\right)_{2}$ の存在を支持している。 これらは $\mathrm{Ba}_{3}\left(\mathrm{PO}_{4}\right)_{2}$ から $\mathrm{Ba}_{3}\left(\mathrm{CrO}_{4}\right)_{2}$ の存在を類推した報告6) そ同様な方法論であるが, $\mathrm{Ba}_{3}\left(\mathrm{CrO}_{4}\right)_{2}$ の場合は, クロムの原子 洒を磁化率測定 (1.71 Bohr マグネトン; 理論值 $1.73 \mathrm{BM}$ ) に より確認しているのに対し， $\mathrm{Ca}_{3}\left(\mathrm{CrO}_{4}\right)_{2}$ に打いてはク口ムの原 子価の直接測定は行なわれていない。また前記研究者の報告には 著者の前報1)の $950^{\circ} \mathrm{C}$ 付近の 熱異常についても触れて打らず, かつ高石灰側のX線回折像の $\mathrm{Ca}_{3}\left(\mathrm{CrO}_{4}\right)_{2}$ のそれと異なる。そこ で $\mathrm{CaO} / \mathrm{Cr}_{2} \mathrm{O}_{3}=3$ を中心とした試料について, 熱処理法, 加熱减 量測定法を前報と若干改め, 化学分析を併用して $\mathrm{Ca}_{3}\left(\mathrm{CrO}_{4}\right)_{2}$ と その生成機構について考察し, 高石灰側の化合物の推定を行なっ たので報告する。

\section{2 実 験 方 法}

\section{$2 \cdot 1$ 試 料}

使用原料は $\mathrm{CaCO}_{3}, \mathrm{Cr}_{2} \mathrm{O}_{3}$ （いずれも邦製特級品）を空気浴中 $110^{\circ} \mathrm{C} ， 3$ 時間以上乾燥したものを用いて所望する組成になるよ 5にそれぞれ定量科取しメノ一乳鉢で乾式混合したものを供試し た。後述する $\mathrm{CaCrO}_{4}-\mathrm{CaCO}_{3}$ 反応に用いた $\mathrm{CaCrO}_{4}$ は $\mathrm{CrO}_{3}$ $\mathrm{Ca}(\mathrm{OH})_{2}$ の湿式反応により合成したものである。すなわち水酸 化カルシウムを水にてミルク状にとき，酸化クロム（VI）水溶液 を滴下反応させ, 過剩の水酸化カルシウムを口別後，口液を濃縮 して粗クロム酸カルシウムを晶出させ, 水で再結晶を行なったの ち, 約 $300^{\circ} \mathrm{C}$, 減圧 $(2 \mathrm{mmHg})$ で脱水乾燥した。

\section{$2 \cdot 2$ 加熱隇量 (TGA) 測定}

装置は前報1)と同じく石英ス ブリングバランス式である。こ の装置は, 重量変化の進行過程 で標的が視野外に出る值前に手 動でハンドルを操作し，零点に 合わせる必要がありそのために 生ずる誤差が比較的大きい。こ の欠点を解消する目的で図 1 の スケールを用いてハンドル操作 を不要とした。すなわち，あら かじめ各線間隔を投影板上の目 盛で読取り, 測定の場合は準 次, 標的を変更して重量変化を 追跡する。

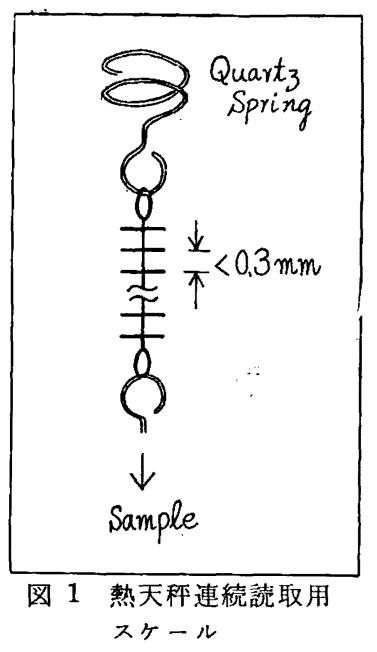

3) W.F.Ford, W.J.Rees, Trans. Brit. Ceram. Soc. 47, 207 (1948) ; 48, 291(1949) ; W. F. Ford, J. White, ibid. 48, 417 (1949).

4) E. P. Glasser, E. F. Osborn, J. Am. Ceram. Soc. 44, 358 (1958).

5）鈴木, 辻田, 窵協 69, 241 (1961).

6) R.Scholder, Angew. Chem. 66, 461 (1954).

\section{$2 \cdot 3$ 示差熱分析 (DTA)}

装置は前報1)と同じ。試料容器つ蓋ははずした状態で, 約 10 ${ }^{\circ} \mathrm{C} / \mathrm{min}$ の昇温速度で測定した。

\section{$2.4 \mathrm{X}$ 線分析}

TGA，DTA の測定後，所定温度から空冷したものにつき銅対 陰極(ニッケルフィルター付), $35 \mathrm{kV}, 10 \mathrm{~mA}, 500 \mathrm{c} / \mathrm{s}, 1-1-0.4$ スリット系列, 時定数 4 秒の条件で走查した。

\section{5 化学分析}

通常のモール塩一過マンガン酸カリウム法を用いて $\mathrm{Cr}^{6+} を$ 定 量した。試料を石英製容器に科取し TGA 測定後, 所定の温度条 件 $\left(800^{\circ} \mathrm{C}\right.$ と $\left.1000^{\circ} \mathrm{C}\right)$ で恒量となるまで保持し，すみやか火取 出し, 約 $3 \mathrm{~N}$-塩酸 $(30 \mathrm{ml})$ 中に容器ごと投入し（容易に溶解し て褐色となる), $100 \mathrm{~m} l$ 定容とする。 $25 \mathrm{~m} l$ を分取しモール塩溶 液（約 $40 \mathrm{~g} /$ 約 $0.1 \mathrm{~N}-\mathrm{H}_{2} \mathrm{SO}_{4} 1 l$ ) $50 \mathrm{ml}$ を添加（緑色）したの ち， $0.1 \mathrm{~N}$ 過マンガン酸カリウム (Fixanal※1) にて余剩 $\mathrm{Fe}^{2+}$ を滴定 (終点紫色) した。所要量を $p \mathrm{~m} l$ とする。モール塩液 50 $\mathrm{m} l$ に対する消費過マンガン酸カリウム量を $q \mathrm{~m} l$ とすると，(1) 式より $\mathrm{Cr}^{6+}(\mathrm{g})$ が求められる。

$$
\mathrm{Cr}=\frac{0.1(q-p)}{1000} \times \frac{52.01}{3} \times \frac{100}{25}
$$

\section{$2 \cdot 6$ 影微鏡観察}

鉱物顕微鏡を用い各加熱試料の遊離石灰 (White 法)，ク口ム 酸カルシウムの存在の有無をX線分析と併行して検索した。

\section{3 実 験 結 果}

\section{$3 \cdot 1 \quad \mathrm{CaCO}_{3}-\mathrm{Cr}_{2} \mathrm{O}_{3}$ 混合系}

3・1・1 TGA 個々の実測曲線はすでに前報1)に記したので省 略するがこれらは図 $2[\mathrm{~A}]$ の 3 曲線に大別され，それぞれ図 2 [B] の DTA 曲線に対応する。そして

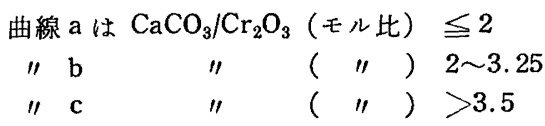

であることも再確認した。 曲線 a の約 $1000^{\circ} \mathrm{C}$ から の減量は $2 \mathrm{CaCrO}_{4} \rightarrow \mathrm{CaO}$. $\mathrm{Cr}_{2} \mathrm{O}_{3}+\mathrm{CaO}+3 / 2 \mathrm{O}_{2}$ によ る。本研究では, b, c 曲 線について考察を進める。 曲線 b $950^{\circ} \mathrm{C}$ 付近で, 減 量を伴了吸熱ピークがあ り, 降温時, $820^{\circ} \mathrm{C}$ 付近に 增量を併 5 発熱ピークを与 点可逆的である ( $b^{\prime}$ 曲線)。 表 1 は各種試料についての 湘定結果である。可逆的重 量変化を伴う試料種では全 隇量から変化量を差引いた むのを減量 ( $\mathrm{g} / \mathrm{g}$-試料) とし 可逆的な変化量は別項に記 載した。石英スプリングの 投影板上での 1 目盛は 0.5

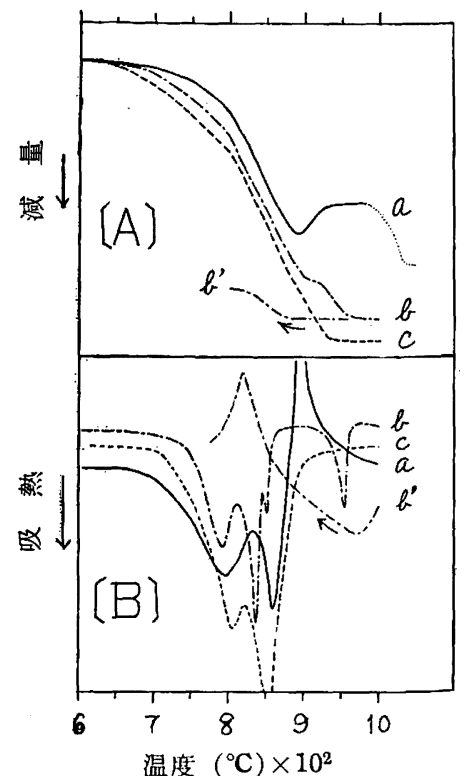
困 $2 \mathrm{CaCO}_{3}-\mathrm{Cr}_{2} \mathrm{O}_{3}$ 混合物の熱天 科 $[\mathrm{A}]$ 扰上び示差熱 [B]曲線

※1 ドィッ製分析用試薬。 


\begin{tabular}{|c|c|c|c|}
\hline \multicolumn{4}{|c|}{ 表 $1 \mathrm{CaCO}_{3}-\mathrm{Cr}_{2} \mathrm{O}_{3}$ 混合系の加熱減量結果 } \\
\hline$\left(\mathrm{CaCO}_{3}^{\sim} / \mathrm{Cr}_{2} \mathrm{Ot}_{3}\right)$ & $\begin{array}{c}\text { 竬料星 } \\
(\mathrm{g})\end{array}$ & $\left(\mathrm{g} / \mathrm{g}-\mathrm{y}^{-y^{-}}\right.$ & 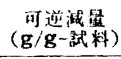 \\
\hline 2.125 & 0.7793 & 0.139 & 0.002 \\
\hline 2.25 & 0.7923 & 0.154 & 0.003 \\
\hline " & 0.7671 & 0.159 & 0.008 \\
\hline 2.5 & 0.8751 & 0.181 & 0.011 \\
\hline " & 0.7873 & 0.182 & 0.011 \\
\hline 2.75 & 0.9661 & 0.204 & 0.010 \\
\hline " & 0.8686 & 0.203 & 0.015 \\
\hline 2.875 & 0.8490 & 0.210 & 0.015 \\
\hline 3 & 0.8365 & 0.217 & 0.013 \\
\hline " & 0.6181 & 0.218 & 0.013 \\
\hline "I & 0.8952 & 0.222 & 0.014 \\
\hline 3.125 & 0.6924 & 0.231 & 0.008 \\
\hline 3.25 & 0.9262 & 0.241 & 0.008 \\
\hline "I & 0.8229 & 0.240 & 0.008 \\
\hline 3.375 & 0.8632 & 0.245 & 0.003 \\
\hline 3.5 & 0.6320 & 0.253 & 0.002 \\
\hline " & 0.6788 & 0.245 & 0.001 \\
\hline 4 & 0.6775 & 0.274 & 0 \\
\hline II & 0.8108 & 0.272 & 0 \\
\hline 5 & 0.7468 & 0.308 & 0 \\
\hline " & 0.8736 & 0.306 & 0 \\
\hline 6 & 0.7312 & 0.325 & 0 \\
\hline "I & 1. 0557 & 0.327 & 0 \\
\hline 6.5 & 0.7558 & 0.334 & 0 \\
\hline 7 & 0.7743 & 0.341 & 0 \\
\hline 7.5 & 0.6749 & 0.351 & 0 \\
\hline 8 & 0.7318 & 0.362 & 0 \\
\hline$" 1$ & 0.7903 & 0.361 & 0 \\
\hline 9 & 0.6994 & 0.369 & 0 \\
\hline 10 & 0.5306 & 0.382 & 0 \\
\hline$" \prime$ & 0.7785 & 0.380 & 0 \\
\hline 15 & 0.5415 & 0.411 & 0 \\
\hline
\end{tabular}

$\mathrm{mg}$ に相当する。

可逆減量とは 800 および $1000^{\circ} \mathrm{C}$ に保持した場合の変化量でこ の往復加熱を $2 \sim 3$ 回行ない温度差による浮力補正後の值である。

$3 \cdot 1 \cdot 2$ 化学分析 $2 \cdot 5$ の方法で分析した結果を表 2 に示す。 な招, モル比 $2.25 \sim 3.50$ は 800 および $1000^{\circ} \mathrm{C}$ からそれぞれ空 冷した試料について分析した。加熱前試料中の Cr* $(\mathrm{g})$ と加熱 後化学分析で得られた $\mathrm{Cr}(\mathrm{g})$ 量を比較すると（2)，(3) から 平均された $\mathrm{Cr}$ の原子価が決定され，(2) 式の Coeff. が 3,2 の場合はそれぞれ $\mathrm{Cr}^{6+}, \mathrm{Cr}^{5+}$ となり，また化学反応式に拈ける $\mathrm{Cr}_{2} \mathrm{O}_{3} 1 \mathrm{~mol}$ に対する反応酸素モルはそれぞれ，1.5，1 となる (4)。

$$
\begin{aligned}
& \text { Cr* }=\frac{0.1(q-p)}{1000} \times \frac{52.01}{\text { Coeff. }} \times \frac{100}{25} \\
& \mathrm{Cr}^{6+}+3 \mathrm{Fe}^{2+} \longrightarrow \mathrm{Cr}^{3+}+3 \mathrm{Fe}^{3+} \\
& \left.\mathrm{Cr}^{5+}+2 \mathrm{Fe}^{2+} \longrightarrow \mathrm{Cr}^{3+}+2 \mathrm{Fe}^{3+}\right\}
\end{aligned}
$$

\begin{tabular}{|c|c|c|c|c|}
\hline $\begin{array}{c}€ \text { ル 比 } \\
\left(\mathrm{CaCO}_{3} / \mathrm{Cr}_{2} \mathrm{O}_{3}\right)\end{array}$ & $\begin{array}{c}\text { 加熱沼度 } \\
\left({ }^{\circ} \mathrm{C}\right)\end{array}$ & $\begin{array}{l}\text { 試将星 } \\
(\mathrm{g})\end{array}$ & 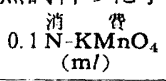 & Coeff. \\
\hline 2.25 & 800 & 0.7280 & 106.0 & 2.75 \\
\hline " & 1000 & 0.7671 & 109.2 & 2.69 \\
\hline 2.50 & 800 & 0.4037 & 52.25 & 2. 61 \\
\hline " & 1000 & 0.7873 & 97.56 & 2.49 \\
\hline 2.75 & 800 & 0.3964 & 48.92 & 2.61 \\
\hline "I & 1000 & 0.8686 & 92.0 & 2.24 \\
\hline 3.00 & 800 & 0.4506 & 42.92 & 2.16 \\
\hline " & 1000 & 0.8952 & 83.12 & 2.10 \\
\hline 3.25 & 800 & 0.3545 & 32.84 & 2.15 \\
\hline " & 1000 & 0.8229 & 71.8 & 2.08 \\
\hline 3.50 & 800 & 0.3144 & 26.8 & 2.14 \\
\hline "I & 1000 & 0.6788 & 55.12 & 2.04 \\
\hline 4.00 & $" 1$ & 0.8108 & 59.68 & 2.03 \\
\hline 5.00 & $"$ & 0.8736 & 53.84 & 2.01 \\
\hline 6.00 & $"$ " & 1.0557 & 57.16 & 2.04 \\
\hline 8.00 & " & 0.7903 & 33.12 & 2.00 \\
\hline 10.00 & " & 0.7785 & 26.80 & 1.98 \\
\hline 15.00 & " & 0.1097 & 2.82 & 2.11 \\
\hline
\end{tabular}

表 $2 \mathrm{CaCO}_{3}-\mathrm{Cr}_{2} \mathrm{O}_{3}$ 混合系の加熱試料の化学分析

$$
\begin{aligned}
& 2 \mathrm{CaO}+\mathrm{Cr}_{2} \mathrm{O}_{3}+1.5 \mathrm{O}_{2}=2 \mathrm{CaCrO}_{4} \\
& x \mathrm{CaO}+\mathrm{Cr}_{2} \mathrm{O}_{3}+\mathrm{O}_{3}=x \mathrm{CaO} \cdot \mathrm{Cr}_{2} \mathrm{O}_{5}
\end{aligned}
$$

ただし $x \mathrm{CaO} \cdot \mathrm{Cr}_{2} \mathrm{O}_{5}$ は便宜上, $\mathrm{Cr}$ の平均原子洒が 5 価で ある場合の一般式とする。

$3 \cdot 1 \cdot 3 \mathrm{X}$ 線分析 $800,1000^{\circ} \mathrm{C}$ 加空冷した陚料の X 線回折 図のらち，主なるのを図 3 に示す。

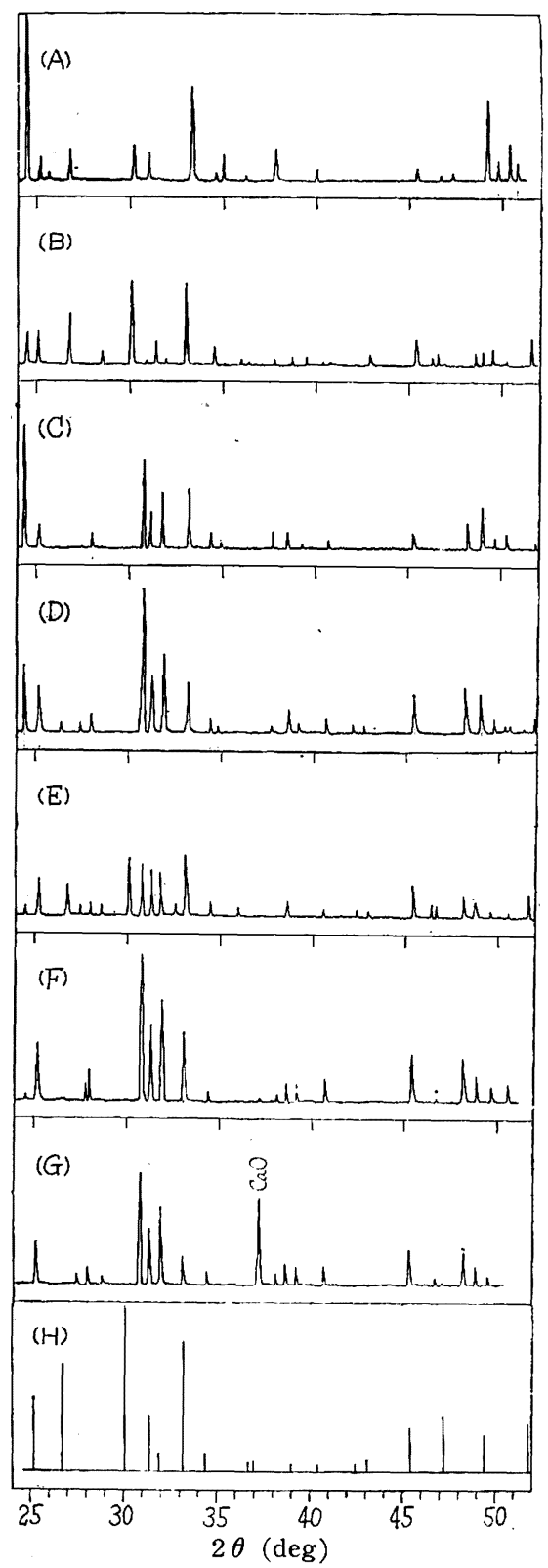

困 3 加熱武料の $\mathrm{X}$ 線回折図 $\left(\mathrm{CaCO}_{3}-\mathrm{Cr}_{2} \mathrm{O}_{3}\right.$ 系) $\left.\mathrm{A}: 2.25 \mathrm{CaCO}_{3}+\mathrm{Cr}_{2} \mathrm{O}_{3}{ }^{\prime} 10000^{\circ} \mathrm{C}\right) \quad \mathrm{E}: 3.0 \mathrm{C}_{2} \mathrm{CO}_{3}+\mathrm{Cr}_{2} \mathrm{O}_{3}\left(1000^{\circ} \mathrm{C}\right)$ $\mathrm{B}: 2.75 \mathrm{CaCO}_{3}+\mathrm{Cr}_{2} \mathrm{O}_{3}("$ " $) \quad \mathrm{F}: 3.5 \mathrm{CaCO}_{3}+\mathrm{Cr}_{2} \mathrm{O}_{3}($ " " ) C : $\quad\left(800^{\circ} \mathrm{C}\right) \quad \mathrm{G}: 6 \mathrm{CaO}_{3}+\mathrm{Cr}_{2} \mathrm{O}_{3}$ (") $\mathrm{D}: 3.0 \mathrm{CaCO}_{3}+\mathrm{Cr}_{2} \mathrm{O}_{3}(")$ ) $\mathrm{H}: \mathrm{Ca}_{3}\left(\mathrm{CrO}_{1}\right)_{2}$ from Glasser et al.

\begin{tabular}{|c|c|c|}
\hline 湘定做（\%) & 理, 解 & 付 折 $/ j$ 洁 \\
\hline 25.44 & 25.68 & \\
\hline 30.84 & 33.34 & モール塭-KM \\
\hline
\end{tabular}

\section{$3 \cdot 2 \mathrm{CaCrO}_{4}-\mathrm{CaCO}_{3}$ 混合系}

合成 $\mathrm{CaCrO}_{4}$ はX 線分析刀結果からは純粋であったが化学分 析（1:3）では石灰灰がゃ多い。

表 3 合成 $\mathrm{CaCrO}_{4}$ の化学分析結果 
混合するにあたり $\mathrm{CaCrO}_{4}$ を $100 \%$ と見なし所定配合比にそ れぞれ秘取して乾式混合した。DTA，TGA 曲線については興味 ある結果を得たが次回に報告することとし，TGA による測定減 量, 化学分析ならびに X 線分析結果について記述する。な报, TGA 測定結果は単味 $\mathrm{CaCrO}_{4} に よ る$ 減量を差引き補正した。

3·2・1 TGA 得られた結果を表 4 亿示す。

表 $4 \mathrm{CaCrO}_{4}-\mathrm{CaCO}_{3}$ 混合系の加熱隇量結果

\begin{tabular}{|c|c|c|c|c|}
\hline$\left(\mathrm{CaCrO}_{4} / \mathrm{CaCO}_{3}\right)$ & $\left(\mathrm{CaCO}_{3} / \mathrm{Cr}_{2} \mathrm{Cr}_{3}\right)$ & $\begin{array}{l}\text { 試料昷 } \\
(\mathbf{g})\end{array}$ & (g/g-減-量料) & $\begin{array}{l}\text { 可逆減量 } \\
(\mathrm{g} / \mathrm{g} \text { - }\end{array}$ \\
\hline 0.25 & 10.0 & 0.6979 & 0.325 & 0 \\
\hline $0.33_{3}$ & 8.0 & 0.7121 & 0.302 & 0 \\
\hline 0.5 & 6.0 & 0.8080 & 0.259 & 0 \\
\hline$"$ & $"$ & 0.6629 & 0.258 & 0 \\
\hline $0.67_{7}$ & 5.0 & 0.6737 & 0.226 & 0 \\
\hline 0.8 & 4.5 & 0.6218 & 0.214 & 0 \\
\hline 1.0 & 4.0 & 0.6736 & 0.191 & 0 \\
\hline 1.143 & 3.75 & 0.7582 & 0.174 & 0.002 \\
\hline $1.33_{3}$ & 3.5 & 0.7902 & 0.158 & 0.010 \\
\hline " & $"$ & 0.7240 & 0.158 & 0.006 \\
\hline 1.6 & 3. 25 & 0.7949 & 0.136 & 0.016 \\
\hline '" & $"$ & 0.7612 & 0.138 & 0.016 \\
\hline 2.0 & 3.0 & 0.8075 & 0.110 & 0.015 \\
\hline$"$ & " & 0.5269 & 0.120 & 0.020 \\
\hline " & " & 0.6278 & 0.116 & 0.019 \\
\hline 2.67 & 2.75 & 0.6901 & 0.099 & 0.021 \\
\hline$"$ & $"$ & 0.4529 & 0.097 & 0.021 \\
\hline " & $"$ & 0.6604 & 0.099 & 0.021 \\
\hline 4.0 & 2.5 & 0.6262 & 0.064 & 0.018 \\
\hline " & $"$ & 0.5860 & 0.067 & 0.018 \\
\hline 8 & 2.25 & 0.6227 & 0.041 & 0.010 \\
\hline
\end{tabular}

$3 \cdot 2 \cdot 2$ 化学分析 $3 \cdot 1 \cdot 2$ の場合と同様に, $800,1000^{\circ} \mathrm{C}$ から 急冷した試料の化学分析結果を表 5 に示す。

表 $5 \mathrm{CaCrO}_{4}-\mathrm{CaCO}_{3}$ 混合系の加熱試料の化学分析

\begin{tabular}{|c|c|c|c|c|}
\hline $\begin{array}{c}モ N \text { 比 } \\
\left(\mathrm{CaCrO}_{4} / \mathrm{CaCO}_{3}\right)\end{array}$ & $\begin{array}{c}\text { 換算モル比 } \\
\left(\mathrm{CaCO}_{3} / \mathrm{Cr}_{2} \mathrm{O}_{3}\right)\end{array}$ & $\begin{array}{c}\text { 加繁温度 } \\
\left({ }^{\circ} \mathrm{C}\right)\end{array}$ & $\begin{array}{l}\text { 試料量 } \\
\text { (g) }\end{array}$ & 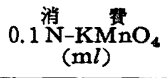 \\
\hline 0.25 & 10.0 & 1000 & 0.6979 & 24.83 \\
\hline 1. $33_{3}$ & 3.5 & 800 & 0.6048 & 52.80 \\
\hline$"$ & $"$ & 1000 & 0.7240 & 60.85 \\
\hline 1.6 & 3.25 & 800 & 0.5140 & 51.10 \\
\hline " & $"$ & 1000 & 0.7612 & 69.30 \\
\hline 2.0 & 3.0 & 800 & 0.5269 & 55.95 \\
\hline " & $"$ & 1000 & 0.6278 & 61.10 \\
\hline 2.67 & 2.75 & 800 & 0.4529 & 52.40 \\
\hline$"$ & $"$ & 1000 & 0.6604 & 66.20 \\
\hline 4.0 & 2.5 & 800 & 0.4792 & 63.00 \\
\hline " & $"$ & 1000 & 0.5860 & 71.65 \\
\hline
\end{tabular}

\section{$3 \cdot 2 \cdot 3 \mathrm{X}$ 線分析と顕微鏡観察}

本混合系の $800,1000^{\circ} \mathrm{C}$ 加熱試料の $X$ 線回折結果(図は省略す る）は, 3・1.3 の結果と対応してほぼ同様の結果を与え, 遊離石 灰の賦存範囲は $\mathrm{CaCrO}_{4} / \mathrm{CaCO}_{3}$ モル比が 2 以上で $\mathrm{CaCO}_{3} / \mathrm{Cr}_{2} \mathrm{O}_{3}$ モル比に換算すると 3 以上となる。

\section{4 考察。}

\section{$4 \cdot 1$ 定性的考察}

Ford らが提出した相図，执よびその一部を修正した Glasser ら結果からは，モル比 $\left(\mathrm{CaO} / \mathrm{Cr}_{2} \mathrm{O}_{3}\right) ※ 23 \mathrm{~K} \mathrm{Ca}\left(\mathrm{CrO}_{4}\right)_{2}$ が生成, 存在し, 3 以上でも安定相であることになるが, $\mathrm{Ca}_{3}\left(\mathrm{CrO}_{4}\right)_{2}$ の 生成温度および機構ならびに分析的決定はなされて扣らず，また 3 以上での化合物種が $\mathrm{Ca}_{3}\left(\mathrm{CrO}_{4}\right)_{2}$ と異なることは 1 で述べた。 $950^{\circ} \mathrm{C}$ 付近の重量変化を伴 熱異常は $\mathrm{X}$ 線回折像にもその相翼 が浔められ， $1000^{\circ} \mathrm{C}$ から急冷した場合は $\mathrm{Ca}_{3}\left(\mathrm{CrO}_{4}\right)_{2}$ の回折像 ※2 以下“モル比”は, $\mathrm{CaO} / \mathrm{Cr}_{2} \mathrm{O}_{3}$ モル比を指す。
と一致するが, $800^{\circ} \mathrm{C}$ から急冷 （または炉内放冷）した場合には， $\mathrm{CaCrO}_{4}$ と, $d=2.90,2.86,2.81$ A 飞特改 3 重線をるつ化合物 $\mathrm{X}$ との混合物である(図 3)。そして Xはモル比 3.5 以上の組成配合試 料を加熱したときに単一化合物と して遊離石灰と共存することがわ かった。化合物 Xの生成過程を調 ベるために, モル比 3 の試料を, DTA の途中 (図 4 の $\mathrm{C}_{1}, \mathrm{C}_{2}, \mathrm{C}_{3}$ ) で空冷してただちにX線分析を行

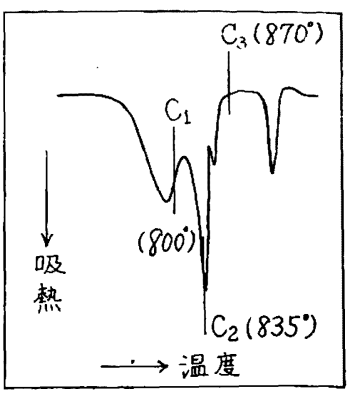

图 $4 \quad 3 \mathrm{CaCO}_{3}+\mathrm{Cr}_{2} \mathrm{O}_{3}$ の 示差熱曲楾略図 （図 $2 \mathrm{~B}$ 曲線 $\mathrm{b}$ 参照）
なった（図5）。

結果を要約すると, $\mathrm{C}_{1}$ では原料の $\mathrm{CaCO}_{3}$, $\mathrm{Cr}_{2} \mathrm{O}_{3}$ がかなり残存し $\mathrm{CaCrO}_{4}$ はすでに生成 している。 $2 \theta=30 \sim$ $32^{\circ}$ 飞拡散回折線を認 める。 $\mathrm{C}_{2}$ では $\mathrm{CaCO}_{3}$, $\mathrm{Cr}_{2} \mathrm{O}_{3}$ ，が微量残存し, $d=2.83,2.92 \AA$ 亿, 新しい回折線を認め る。 $\mathrm{C}_{3}$ では原料は最 早や存在せず化合物 X と $\mathrm{CaCrO}_{4}$ の混合物か らなり $1000^{\circ} \mathrm{C}$ から徐 冷した回折像と一致す る。また $\mathrm{C}_{1}, \mathrm{C}_{2}, \mathrm{C}_{3}$ とも遊離 $\mathrm{CaO}$ は認め られなかった。以上の

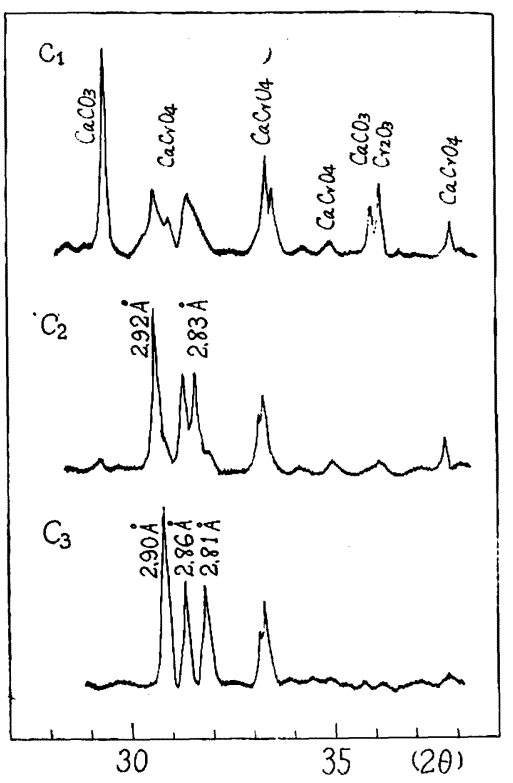

因 5 化合物 Xの生成過程
結果から， $\mathrm{CaCO}_{3}$ の分解生成物 $\mathrm{CaO}$ はただちに $\mathrm{Cr}_{2} \mathrm{O}_{3}$ と反応 して $\mathrm{CaCrO}_{4}$ を生成する。 $d=2.83,2.92 \AA$ の回折線は $\mathrm{C}_{3}$ の $d=2.81 ， 2.90 \AA$ に対し格子膨張に起因寸ると考穴られる。図 4 の $\mathrm{C}_{2}-\mathrm{C}_{3}$ 間の小吸熱ピークは膨張格子の正規格子への転移熱に よるものであろう。

\section{$4 \cdot 2$ 定量的考察}

熱分析， X 線分析の結果を定性的に考察してモル比が $2 \sim 3.5$ の範用では，約 $950^{\circ} \mathrm{C}$ K(5) 式の可逆反応

$$
\mathrm{CaCrO}_{4}+\mathrm{X} \rightleftharpoons \mathrm{Ca}_{3}\left(\mathrm{CrO}_{4}\right)_{2}+\mathrm{O}_{2}
$$

があること，扰よび化合物 Xは未報告の安定化合物であることを 知った。TGA, 化学分析などの結果を検討し化合物 Xについて 考察する。

表 1，4 の測定結果は試料量が $1 \mathrm{~g}$ 弱であり，これを相当分 子量※3 に换算して酸化モルなどを計算するのは熱天科の精度か ら考えて無謀であるが後述する化学分析結果との比較扣よび, 今 後の反応解析のための一資料として計算結果を図 6,7 亿示す。

図 6 の酸化反応関与した酸素モル数（-O-）の計算は（6） 式によった。すなわち可逆减量を差引いた測定减量 $w(\mathrm{~g} / \mathrm{g}$-試 料), 酸化クロム (V) $1 \mathrm{~mol}$ に対する炭酸カルシウムモル数 $m$, および混合試料の相当分子量 $M W$ から,

※3 $\mathrm{Cr}_{2} \mathrm{O}_{3} 1 \mathrm{~mol}$ を含有する混合物の分子量。 


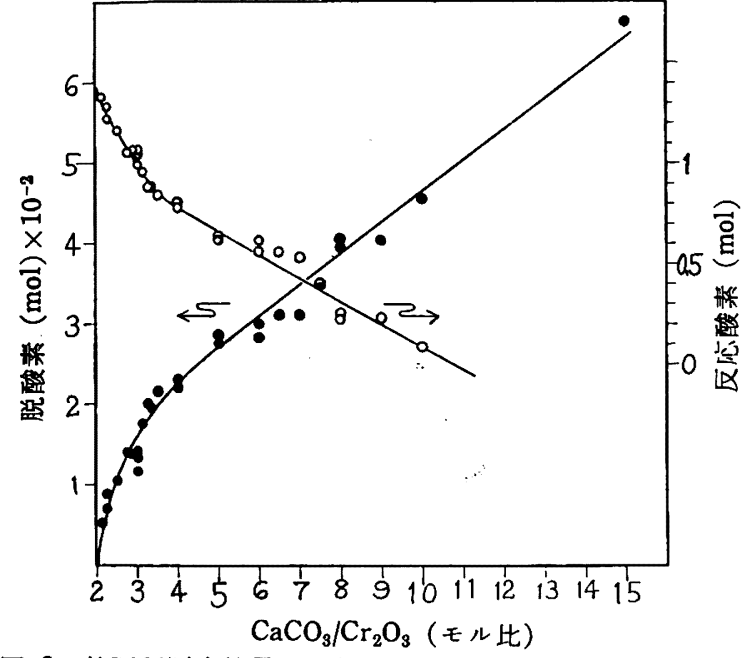

図 6 熱天秤測定結果から得た相当分子量あたりの反応酸素 モル数 (-○-) および化合物 $\mathrm{X}$ 生成に要する $\mathrm{CaCrO}_{4}$ $1 \mathrm{~mol}$ あたりの脱酸素モル数 (-○-) $\left(\mathrm{CaO}_{3}-\mathrm{Cr}_{2} \mathrm{O}_{3}\right.$ 混合系 $)$

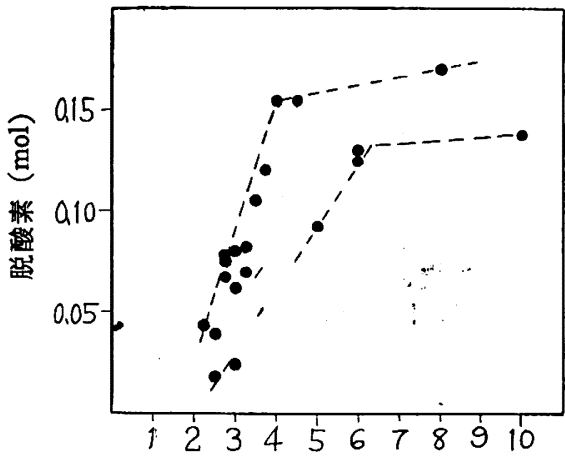

換算 $\mathrm{CaO} / \mathrm{Cr}_{2} \mathrm{O}_{3}$ (モル比)

図 7 熱天秤測定結果から得た化合物 $\mathrm{X}$ 生成に要する $\mathrm{CaCrO}_{4} 1 \mathrm{~mol}$ あたりの脱酸素モル数 $\left(\mathrm{CaCrO}_{4}-\mathrm{CaCO}_{3}\right.$ 掍合系)

反沁酸素モル数 $=(44 m-w \cdot M W) / 32$

となる。（）内は $m \mathrm{CaCO}_{3}$ 単味の理論減量値と, 酸化反応を 伴った測定减量值の差で反応関与した酸素の量（g）を表わす。 また $m \mathrm{CaCO}_{3}+\mathrm{Cr}_{2} \mathrm{O}_{3}$ を空気中で加熱したとき，初期生成物ク、 ロム酸カルシウムは $m>2$ で酸化カルシウムと反応する(式 5 )。 クロム酸カルシウム $1 \mathrm{~mol}$ 当りの脱酸素モル数を計算して点緅 したのが図6の-の-曲線, 図7である。図6の-○-曲線は, 後に述べるように $m \geqq 3$ で生成す化合物のク口ムの平均原子価が 5 価であることから， $m \geqq 3$ で 1 の定値を与えるはずであるが， 測定値は漸次低値を与える。 $m \div 3$ までが，熱天伻による測定の 信頼限界といえるであろ5。 $m>3$ では今後の反応解析のための 補正曲線となる。 $950^{\circ} \mathrm{C}$ 付近の可逆減量をまとめたのが四 8,9 で，図 8 は表 1 の結果 ( $\mathrm{g} / \mathrm{g}$-試料) を，図 9 は，表 4 から計算し たクロム酸カルシウム $1 \mathrm{~mol}$ 当りの脱酸素モル数をモル比に対 して点綴したものである。

図 8，9 からモル比 2 3.5 の間に可逆的な変化量が喼められ， 最大減量はモル比 2.75 付近に存在することがわかった。図 9 か ら，ほぼ $8 \mathrm{~mol}$ のクロム酸カルシウムから $1 \mathrm{~mol}$ の酸素が湤出 することになるが、ここにクロム酸カルシウムは混合試料中のク ロム酸カルシウムを表わし，その一部は $950^{\circ} \mathrm{C}$ 以下で化合物 $\mathrm{X}$ と 反応（式 5) するのに消費されるので実際の可逆反応では $8 \mathrm{~mol}$

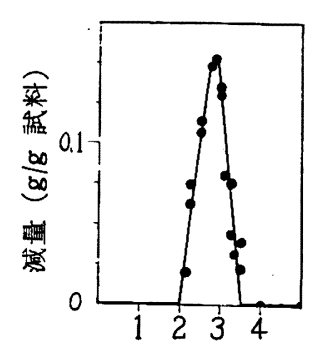

$$
\mathrm{CaCO}_{3} / \mathrm{Cr}_{2} \mathrm{O}_{3} \text { (モル比) }
$$

図 $8800 \sim 1000^{\circ} \mathrm{C}$ 間の可逆 的重量变化

$\left(\mathrm{CaCO}_{3}-\mathrm{Cr}_{2} \mathrm{O}_{3}\right.$ 混合系)

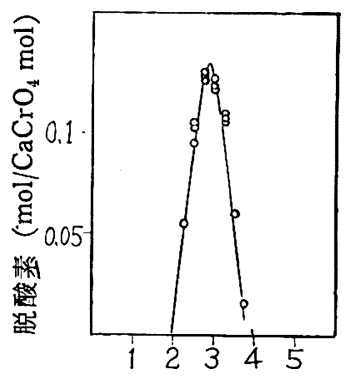

換算 $\mathrm{CaO} / \mathrm{Cr}_{2} \mathrm{O}_{3}$ (モル比)

因 $9800 \sim 1000^{\circ} \mathrm{C}$ 間の可逆 的重量変化

$\left(\mathrm{CaCrO}_{4}-\mathrm{CaCO}_{3}\right.$ 识合䒺)

以下のクロム酸カルシウムから酸素 $1 \mathrm{~mol}$ が出ることになるで あろう。続いて化学分析によって得た值について，考察を進めた い。表 2 の結果で, 高石灰側の Coeff. が 2 に近似し生成化合物 の Cr の平均原子価が 5 洒であることが推定された。TGA 後の 試料は塩酸に徐々に溶解して褐色となる。この溶液はポーラログ ラム（条件：直流，支持塩 $0.1 \mathrm{~N}$-塩化カリウム，添加剤ゼラチ ン, 感度 $0.04, \mathrm{PC} 25$; 柳本製 $)$ から $\mathrm{Cr}^{3+}, \mathrm{Cr}^{6+}$ の半波電位 $(-0.85,-0.3$ vs. S.C.E. $)$ を認め, また, 酢酸鉛溶液の添加 によるクロム酸鉛の沈股捄よびアンモニア添加による水酸化クロ ムの沈殿生成からも定性的に $\mathrm{Cr}^{3+}, \mathrm{Cr}^{6+}$ の共存を認めた。表 2 の分析結果から相当分子量当りの $\mathrm{Cr}^{3+}, \mathrm{Cr}^{6+}$ のグラム原子数を

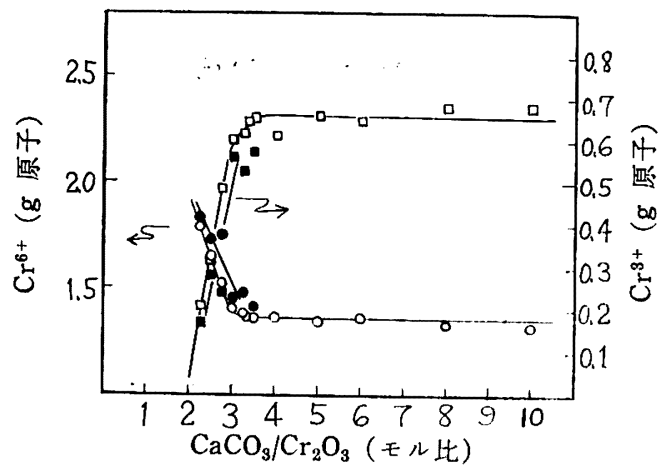

図 $10800^{\circ} \mathrm{C}(○, \square)$ および $1000^{\circ} \mathrm{C}(\bigcirc, \square)$ ょり

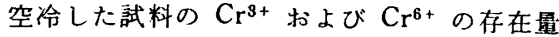
$\left(\mathrm{CaCO}_{3}-\mathrm{Cr}_{2} \mathrm{O}_{3}\right.$ 涩合采)

モル比に対して点経したのが 図 10 である。加熱試料中の $\mathrm{Cr}^{\mathrm{s}+}$ 量の計算は供試原料中 の $\mathrm{Cr}^{3+}$ (グラム原子) より 分析した $\mathrm{Cr}^{6+}$ (グラム原子) を差引いて得た。同様の方法 で表 5 からクロム酸カルシウ ム $1 \mathrm{~mol}$ を含む混合系につ いて計算した結果を㘠 11 に 示した。

○, 口は $800^{\circ} \mathrm{C}$ 急冷武料中 の, ○, 口は $1000^{\circ} \mathrm{C}$ 急冷試 料中の $\mathrm{Cr}^{3+}, \mathrm{Cr}^{6+}$ 值である が, この温度差による $\mathrm{Cr}^{3+}$, $\mathrm{Cr}^{6+}$ 值の差異は $950^{\circ} \mathrm{C}$ 付近 における重量変化，すなわた

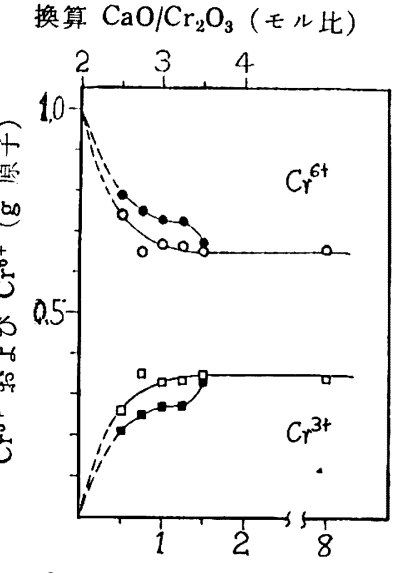

$\mathrm{CaCO}_{3}$ モル数 $/ 2 \mathrm{CaCrO}_{4}$

図 $11800^{\circ} \mathrm{C}(\boldsymbol{O}$ ，回) およ゙ 1000 “C ( $， \square)$ 上り空冷した就料

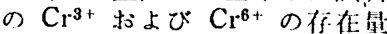
$\left(\mathrm{CaCrO}_{4}-\mathrm{CaCO}_{3}\right.$ 覑命票) 
（5）式のクロム酸カルシウムの反応関与を示している。図 10 , 11 から $m>3$ では $\mathrm{Cr}^{3+}, \mathrm{Cr}^{6+}$ 值は一定值を示し, 比 $\mathrm{Cr}^{6+} / \mathrm{Cr}^{3+}$ 值は 2 となり加熱試料中のクロムの原子価の平均值は 5 価となる。 いま化合物 $\mathrm{X}$ を $x \mathrm{CaO} \cdot \mathrm{Cr}_{2} \mathrm{O}_{5}$ としさらに $x^{\prime} \mathrm{CaO} \cdot 4 \mathrm{CrO}_{3} \cdot \mathrm{Cr}_{2} \mathrm{O}_{3}$ と書き表わされたとして，モル比 $2.25 \sim 3.5$ 配合試料の $800^{\circ} \mathrm{C}$ 加熱急冷物の化学分析結果から $x^{\prime}$ を計算した。すなわち $\mathrm{Cr}^{6+}$ の分析値から $x^{\prime} \mathrm{CaO} .4 \mathrm{CrO}_{3} \cdot \mathrm{Cr}_{2} \mathrm{O}_{3}$ 化合物生成に要する $\mathrm{Cr}^{6+}$ 差引き $\mathrm{CaCrO}_{4}$ 存在量を求め, 試料中の全カルシウムからク口 ム酸カルシウム生成に要するカルシウム分を差引いて，その差を $x^{\prime}$ とした。結果は 9.0１1.2 の範囲内でこれょり $x^{\prime}$ を決定す るのは不可能であったが大略の示唆を与える。モル比 3.5 を境と
した遊離不灰の有無, 図 8,9 の可逆減量の有無などから考えて 化合物 Xは $3.5 \mathrm{CaO} \cdot \mathrm{Cr}_{2} \mathrm{O}_{5}$ すなわち $\mathrm{Ca}_{7} \mathrm{Cr}_{4} \mathrm{O}_{17}$ に相当すること が判り式（5）は（7）式で装き表わされる。 $4 \mathrm{CaCrO}_{4}+2 \mathrm{Ca}_{7} \mathrm{Cr}_{4} \mathrm{O}_{17} \rightleftharpoons 6\left[\mathrm{Ca}_{3}\left(\mathrm{CrO}_{4}\right)_{2}\right]+\mathrm{O}_{2}$

(7) 式は $950^{\circ} \mathrm{C}$ 付近の可近減量を示す反応式であるが同式の 左辺から可逆減量が最大になる $\mathrm{CaO} / \mathrm{Cr}_{2} \mathrm{O}_{3}$ モル比は 2.75 とな り図 8，9 の結果と良い一致を示す。また $\mathrm{Ca}_{7} \mathrm{Cr}_{4} \mathrm{O}_{17}$ 生成の反 応式は（8）となる。

$$
4 \mathrm{CaCrO}_{4}+3 \mathrm{CaO}=\mathrm{Ca}_{7} \mathrm{Cr}_{4} \mathrm{O}_{17}+\mathrm{O}_{2}
$$

(昭 37 年 4 月 5 日, 日本化学会 15 年会講演)

\section{酸化鉄粒子の大きをと顔料 適 性}

（昭 和 37 年 8 月 27 日 受 理）

\section{信岡聰一郎・長 江 明・阿度 和 明・二階堂富子*}

形のちがった酸化鉄について，粒子の大きさと，顔料としての諸性質との関係について調へた。試料としては（1） 硫酸鉄の加水分解により成長させたGoethite の針状粒子，（2）Goethite 脱水してえられる針状形 Hematite，(3) 水酸化鉄（III）の加王水熱処理により生成する立方形 Hematite の 3 種類について粒子の大きさと, 㓌ぺい力, 吸油量, 色との関係を検剷し次の結果を壳た。

顔料粒子に光が当った場合，粒子径が小さいほど表面反射が增し，陰ぺい力，明度ともに大きくなる。ところが，その 大きさが光の波長以下の微小粒子になると, 普通の反射, 屈折と異なった光の散乱, 回折などの現象により顔料が透明性 をおびてくる。したがって粒子の大きさと，陰ぺい力，明度との間においては最大点が見出され，またその最大点は陰ぺ い力の場合と，明度の場合とで，粒子径が近似している。すなわち，

（1）針状形 Goethite の場合, 粒子の幅 150〜177 m $\mu$ で陰ぺい力, 明度ともに最大值を示した。

（2）針状形 Hematite の場合，粒子の幅 $150 \mathrm{~m} \mu$ 付近で陰ぺい力は最大, 約 $113 \mathrm{~m} \mu$ で明度が最大であった。

（3）立方状 Hematite の場合, 粒子径 $186 \mathrm{~m} \mu$ 以下では未だ陰ぺい力, 明度ともに最大点が見出せなかった。

\section{1 緒 言}

顔料粒子の大きさは，色，院ぺい，吸油量, 着色力, あるい は塗料にしたときのレオロジ一的性質, 塗膜の光沢, 強さなどに 影響を扣よぼす重要な性質である。同じ化合物の顔料でも粒子の 大きさによって，その品位はかわってくる。とくに粒子の大きさ さが光の波長の $1 / 2$ 以下の微小粒子になると, 普通の反射, 屈折 とちがった, 光の散乱 Scattering, 回折 Diffractionなどの現象 によって色，除ぺい，着色力にかなりの影響を扣よぼすことが 知られている1 4)。

Depew，Eide ${ }^{5)}$ は亜鉛華の 粒子の形，大きさと最大陰ぺい力 との関係沉つて研究している。Hughes ${ }^{6)}$ は種々の白色顔料に

* 大阪工業技術試験所 : 大阪市大淀区大仁西.

1) P.B.Mitton, L.W. Vejnoska, M. Frederick, Offic. Digest 33, 1264 (1961).

2) P.B. Mitton, L. W. Vejnoska, M. Fredrick, ibid. 34, 73 (1962).

3) E. J. Bowen, "Chemical Aspects of Light" Oxford at the Clarenden Press (1949) p. 39.

4) 信岡, 安藤, 大工試季報 6, 135 (1955).

5) H. A. Depew, A.C.Eide, Ind. Eng. Chem. 32, 537 (1940).

6) W. Hughes, J. Oil and Colour Chemists' Assoc. 35, 535 (1952).
ついて粒子の大きさと光の散乱, 陰ぺい力, 着色力との間の関係 について, Fresnel の法則, Rayleich7) の式により, ベヒクルを 変えて算出し，奏験と対比して考察している。その他顔料としての 最適粒子径を求める研究 ${ }^{8,9)}$ は見られるが，酸化鉄に関して ${ }^{10 \sim 12)}$ は二,三あるのみである。

種々の形，大きさの顔料粒子を自由に作ることは，むつかしい 問題であるが, たまたま, 酸化鉄について 3 種類の形で, 粒子径 のことなる陚料を作ることができた。すなわち，（1）針状形の 黄色酸化鉄 Goethite $\alpha-\mathrm{FeOOH}$ （2）（1）を脱水した針状形 $\alpha$ $\mathrm{Fe}_{2} \mathrm{O}_{3}$, Hematite, (3) 水熱法によってえた立方形の $\alpha-\mathrm{Fe}_{2} \mathrm{O}_{3}$ Hematite。この 3 種類の試料について粒子の大きさと, 顔料適性 との関係について検討した。

\section{2 試 料 の 調 製}

\section{$2 \cdot 1$ 試料 I $\alpha-\mathrm{FeOOH}^{13)}$ 針状 Goethite}

7) Lord Rayleigh, Phil. Mag., 35, 373 (1918).

8) R.H. Kienle, C. Maresh, J. Oil and Colour Chemists Assoc. 36, 619 (1953).

9) W. Lützkendorf, Farbe u. Lack, 53, 7 (1953).

10) H. Birnbaum, J. Appl. Phys., 18, 27 (1947).

11) 信岡, 安藤, 大工試季報 6, 135 (1955).

12）高四，粉体扰よび粉末十金 $4 ， 41$ (1956).

13) J. J. Mattiello, "Protective \& Decorative Coatings, II" John Wiley \& Sons, Inc., New York (1942) p. 300. 